\title{
Sosyal Hakların Gerçekleştirilmesinin Amerikan Devletleri Örgütü Sisteminde Denetimi ${ }^{1}$
}

\author{
Ayşen SEYMEN ÇAKAR ${ }^{2}$
}

\section{Öz}

Sosyal haklar kısaca, herkesin insan onuruna uygun şekilde yaşamasını güvence altına alan haklardır. Sosyal haklar 19. yüzyılın ikinci yarısında genel kabul görmüş ve ILO'nun kurulmasıyla da evrensel bir boyut kazanmıştır. Sosyal hakların gerçekleştirilmesi, bu hakların bireyler tarafından her hangi bir engelle karşılaşmaksızın kullanılabilmesi olarak anlaşılabilir. Sosyal haklar, gerçekleştirilebilmeleri amacıyla devlete hem pozitif, hem de negatif yükümlülükler yüklemektedir. Bu yükümlülüklerden en önemlisi ise sosyal hakların ihlali durumunda etkin bir yargılama yapılması yükümlülüğüdür. Gerçekte aynı anlama gelmemekle birlikte, sosyal hakların gerçekleştirilebilirliği denildiğinde akla ilk gelen, yargılanabilirliktir. Ekonomik ve sosyal hakların yargılanabilirliği hakkındaki tartışmanın, eski ve klişeleşmiş bir tartışma olduğu söylenebilir. Sosyal hakların gerçekleştirilmesi, Amerikan Devletleri Örgütü Sisteminde, Amerikalılar arası İnsan Hakları Komisyonu ve Amerikalılar Arası İnsan Hakları Mahkemesi önünde denetlenebilmektedir.

Anahtar Kelimeler: Sosyal haklar, Amerikan Devletleri Örgütü, Amerikalılar Arası İnsan Hakları Komisyonu, Amerikalılar Arası İnsan Hakları Mahkemesi.

\section{Audit of The Realization of Social Rights In The System of The Organization of American States}

\begin{abstract}
Social rights are briefly the rights that guarantee everyone to live in accordance with human dignity. Social rights were generally accepted in the second half of the 19th century and gained a universal dimension through the establishment of the ILO. The realization of social rights can be understood as the use of these rights by individuals without encountering any obstacles. Social rights have both positive and negative obligations to the state in order to be realized. The most important of these obligations is the obligation to make an effective trial in case of infringement of social rights. Although it does not really mean the same thing, the first thing that comes to mind when it is called the feasibility of social rights is judicial. It can be said that the debate about the justiciability of economic and social rights is an old and stereotyped debate. The realization of social rights can be monitored in the System of the Organization of American States, before the Inter-American Commission on Human Rights and the Inter-American Court of Human Rights.
\end{abstract}

Key Words: Social rights, The Organization of American States, The Inter-American Commission on Human Rights, The Inter-American Court of Human Rights.

\footnotetext{
${ }^{1}$ Bu makale, Kocaeli Üniversitesi Sosyal Bilimler Enstitüsü Kamu Hukuku Doktora Programında tamamlanmış olan Sosyal Hakların Gerçekleşsirilebilirliği adlı tez çalışmasından türetilmiştir

${ }^{2}$ Dr., aysen.seymen@bilecik.edu.tr
} 


\section{Giriş}

Sosyal haklar, sosyal devletin gereği olan sosyal adaleti gerçekleştirmek için insan onuruna uygun asgari yaşam standartlarının belirlenerek, herkesin buna uygun bir yaşam seviyesine sahip olmalarını sağlamaya ve korumaya yönelik insan haklarıdır.

Sosyal haklar 19. yüzyılın ikinci yarısında genel kabul görmüş ve Uluslararası Çalışma Örgütü'nün (ILO) kurulmasıyla da evrensel bir boyut kazanmıştır. Sosyal hakların gerçekleştirilmesi, bu hakların bireyler tarafından her hangi bir engelle karşılaşmaksızın kullanılabilmesi olarak anlaş1labilir. Sosyal haklar, gerçekleştirilebilmeleri amacıyla devlete hem pozitif, hem de negatif yükümlülükler yüklemektedir. Bu yükümlülüklerden en önemlisi ise sosyal hakların ihlali durumunda etkin bir yargılama yapılması yükümlülüğüdür. Gerçekte aynı anlama gelmemekle birlikte, sosyal hakların gerçekleştirilebilirliği denildiğinde akla ilk gelen, yargılanabilirliktir. Pek çok yazar sosyal hakları, kaynak gerektirdiğinden bahisle yargılanamaz nitelikte haklar olarak kabul etmektedir. Bazı anayasalarda da sosyal hakların devletin mali gücü oranında gerçekleştirilebileceği vurgulanarak sosyal haklar program hükümler şeklinde düzenlenmektedir. Oysa ki, günümüzde negatif veya pozitif karakterli olmasına bakılmaksızın hemen her hak türünün devletin kaynak kullanmasını gerektirdiği ortadadır. İnsan haklarının bütünlüğü ve birbirine bağlılığı ilkesi de negatif-pozitif hak ayrımını reddetmektedir. Ekonomik ve sosyal hakların yargılanabilirliği hakkındaki tartışmanın, eski ve klişeleşmiş bir tartışma olduğu söylenebilir. Bu çalışmada da gerçekleştirilebilirlikten kasıt sosyal hakların yargı önünde sübjektif hak olarak ileri sürülebilmesidir.

$\mathrm{Bu}$ çalışmanın amacı, Amerikan Devletleri Örgütü Sisteminde yapılan denetimler emsal tutularak sosyal hakların gerçekleştirilebilir nitelikte haklar olduğunu göstermektir. Konunun seçilme sebebi ise sosyal hakların halen konusu olduğu yargılanamazlık tezlerine kuramsal ve içtihadi bir bütünlük içerisinde yanıt verme düşüncesidir.

Roosevelt'in "dört özgürlük demeci" ismiyle bilinen, 1941 tarihli State of the Union söylevinde, dört temel insan özgürlüğü sayılmış ve bu özgürlüklerden üçüncüsünün, dünya lügatine ekonomik anlayış olarak çevrilen ve her millete kendi üyeleri için sağlıklı bir barış dönemi yaşantısını garantileyen, dünyanın her yerinde yoksulluktan kurtulma özgürlüğü olduğu ifade edilmiştir (Whelan ve Donnelly, 2007, s. 912).

Sosyal haklar bugün için uluslararası ve bölgesel kuruluşlar ve pek çok ulusal mahkemeler önünde dava edilebilir olduğu gibi bu hakların yargılanamaz nitelikte oldukları iddialarının herhangi bir güvenilirliği olmadığından bu iddiaları sürdürmek giderek zorlaşmaktadır. Sosyal hakların gerçekleştirilmesinin denetlendiği bölgesel sistemlerden bir tanesi de Amerikan Devletleri Örgütü sistemidir. Amerikan Devletleri Örgütü'nde sosyal hakların gerçekleştirilmesinin denetimini Amerikalılar Arası İnsan Hakları Komisyonu ve Amerikalılar Arası İnsan Hakları Mahkemesi yapmaktadir. 


\section{Amerikan Devletleri Örgütü}

İkinci Dünya Savaşı sonrasında, Avrupa'da olduğu gibi Amerika kıtasında da bölgesel örgütlenmeye gidilmiştir. Amerika kıtasındaki örgütlenmenin en önemli aşaması, "Amerikan Devletleri Örgütü”nün kurulması ile gerçekleşmiştir (Ural Uslan ve Güner, 2014, s. 310). Bu Örgüt, 30 Nisan 1948'de Kolombiya'nın Bogota kentinde Örgüt Şartı'nın imzalanmasıyla kurulmuştur. Şart, 13 Aralık 1951 tarihinde Kolombiya'nın 14. devlet olarak onay vermesiyle yürürlüğe girmiştir (Ural Uslan ve Güner, 2014, ss. 310-311).

\section{Amerikan İnsan Hakları ve Ödevleri Bildirgesi}

Mayıs 1948'de, Birleşmiş Milletler Genel Kurulu'nun, İnsan Hakları Evrensel Bildirgesi'ni kabul etmesinden yedi ay önce Amerikan Devletleri Örgütü, İnsan Hakları ve Ödevleri Amerikan Bildirgesi'ni kabul etmiştir. Bu bildirge, -hem kişisel ve siyasal, hem de ekonomik, sosyal ve kültürel olmak üzere- bir dizi temel insan hakları ortaya koymuştur. Bu sayede, Amerikan Devletleri Örgütü, yaşama hakkı, özgürlük, eşitlik, oy hakkı gibi geleneksel temel haklar ile eğitim hakkı (md. 12), kültür hakk1 (md. 13), çalışma hakkı (md. 14) ve sosyal güvenlik (md. 16) haklarını yan yana sıralamıştır (Cavallaro ve Schaffer, 2004, s. 224). Amerikan Devletleri Örgütü Şartı'nın kabul edildiği diplomatik konferansta ilan edilen Amerikan İnsan Haklanı ve Ödevleri Bildirisi, Şartın insan haklarını tanımlayan belgesi konumuna gelmiştir (Ural Uslan ve Güner, 2014, s. 311). 2 Mayıs 1948 tarihinde, Dokuzuncu Uluslararası Amerikan Devletleri Konferansı'nda ilan edilen “Amerikan İnsan Hakları ve Ödevleri Bildirisi” vatandaşlara insan haklarını bildiren ve bu bağlamda vatandaşların korunması için devletlere ödevler yükleyen ve bir uluslararası örgütçe yapılmış ilk bildiridir (Aslan, 2012, s. 267).

Amerikan İnsan Hakları ve Ödevleri Bildirgesi; aile kurma ve ailenin korunması hakkı (md. 6), annelerin ve çocukların korunması hakkı (md. 7), sağlığın ve refahın korunması hakkı (md. 11), eğitim hakkı (md. 12), kültürden yararlanma hakkı (md. 13), çalışma ve adil ücret hakkı (md. 14), dinlenme zamanı ve bundan yararlanma hakkı (md. 15), sosyal güvenlik hakkı (md. 16), örgütlenme hakk1 (md. 22) gibi sosyal, ekonomik ve kültürel haklara bünyesinde yer vermiştir (www.ihop.org.tr/dosya/sozlesme/amerikaninsanhaklariodevleri bildirgesi.doc/25.10.2016).

Amerikan Devletleri Örgütü'nün bir organı olan Amerikan Hukuk Komitesi 1949 yılında Amerikan İnsan ve Hakları ve Ödevleri Bildirgesi'nin, Örgüt Şartından ayrı bir metin olduğu ve yasal sözleşmesel yükümlülükler doğurmadığını belirtmiş fakat 1970 yılında yürürlüğe giren Buenos Aires Protokolü ile Örgüt Şartı'nın değişmesiyle birlikte Bildirgenin statüsü de değişerek, Örgüt Şartı, Bildirgeyi Şart tarafından korunan hakların kataloğunu içeren belge olarak kabul etmiş, ayrıca Amerikan İnsan Hakları Mahkemesi'nin 1989 yılında verdiği tavsiye niteliğindeki kararında, Bildirgenin Örgüt üyesi devletler için yükümlülük içeren bir metin olduğu vurgulanmıştır (Ural Uslan ve Güner, 2014, s. 312). 


\section{Amerikan İnsan Hakları Sözleşmesi}

Amerikan İnsan Hakları Sözleşmesi, 22 Kasım 1969 tarihinde Kosta Rika’nın San Jose kentinde imzalanarak 18 Temmuz 1978 tarihinde yürürlüğe girmiştir (Çelebi, 2012, s. 67). Sözleşmede ekonomik, sosyal ve kültürel haklar tek bir maddeye, madde 26'ya indirgenmiştir. Aşamalı gerçekleştirme ismini taşıyan bu maddeye göre, "Taraf devletler, Buenos Aires Protokolü ile değiştirilen Örgüt Şartı'nda ortaya konulan ekonomik, sosyal, eğitimsel, bilimsel ve kültürel standartlarda belirtilen hakların aşamalı olarak tam gerçekleştirilmesi amacıyla özellikle ekonomik ve teknik yapıda olmak üzere ulusal ve uluslararası işbirliği yoluyla yasama veya diğer uygun vasıtalar ile önlemler almayı taahhüt ederler (Cavallaro ve Schaffer, 2004, ss. 224-225).

Sözleşme, Avrupa İnsan Hakları Sözleşmesi (AİHS) gibi, kişisel ve siyasal haklarla sınırlıdır. Bu Sözleşme'nin, AİHS’nden tek farkı, mülkiyet hakkına da yer vermesidir. Buna karşın Amerika'da, Avrupa Sosyal Şartı ya da Birleşmiş Milletler Ekonomik, Sosyal, Kültürel Haklar Sözleşmesi benzeri düzenlemeler yoktur (Donnelly, 1995, s. 228). Sözleşme'nin ikinci bölümü kişisel ve siyasal haklara ayrılmakla birlikte, bu başlık altında bazı sosyal haklara da yer verilmiştir. Bunlar, örgütlenme özgürlüğü (md. 16), aileye ilişkin haklar (md. 17), çocuk hakları (md. 19) olarak sayılabilir (https://burakgemalmaz.files.wordpress.com/2015/05/02. pdf /25.10.2016).

\section{Amerikan İnsan Hakları Sözleşmesi’ne Ekonomik, Sosyal ve Kültürel Haklar Alanında}

\section{Ek Protokol}

1988 yılında Amerikan İnsan Hakları Sözleşmesi’ne Ekonomik, Sosyal ve Kültürel Haklar Alanında Ek Protokol veya diğer adıyla San Salvador Protokolü kabul edilmiştir. San Salvador Protokolü; ekonomik, sosyal ve kültürel haklar arasında, başvuru konusu olabilecek haklar ve rapor gönderme usulüne tabi olan haklar ayrımı yapmaktadır. Bu ayrıma göre, San Salvador Protokolü’nün sadece sendikal haklara ilişkin 8. maddesi ve eğitim hakkına ilişkin 13. maddesi başvuru konusu edilebilecektir, bunun dışındaki haklar ise ancak, gönderilen raporlar üzerinden yapılan değerlendirmeler yoluyla denetlenmiş olacaktır (Yücel Dericiler, 2014, s. 220).

\section{Amerikan Sosyal Şartı}

Amerikan Sosyal Şartı, Örgüt Genel Kurulu'nun kırk ikinci düzenli oturumunda 4 Haziran 2012 tarihinde kabul edilmiştir. Şartın birinci bölümü sosyal adalet, eşitlik temelli gelişme ve demokrasi konusuna ayrılmıştır. Birinci maddede, üye devletlerin Amerikan halklarının sosyal adalet talebini karşılamakla yükümlü olduğu belirtilmiştir. Üye devletler, ekonomik, sosyal ve kültürel hak ve ilkelerin tam olarak gerçekleştirilmesini, demokratik süreçleri ve mevcut kaynaklarına uygun olarak ihtiyaçları için en etkili ve uygun olduğunu düşündükleri politikalar ve programlar yoluyla ilerletmeyi taahhüt ederler (md.2/2). Şartın, sosyal kalkınma, firsat eşitliği ve ayrımcılık yasağı başlığını taşıyan üçüncü bölümünde, üye devletlerin, herkes için eşitlik ve sosyal kapsama ile sosyal gelişimi teşvik etme ve gerçekleştirme sorumluluğuna sahip olduğu belirtildikten sonra, sosyal haklar, devlet 
yükümlülükleri şeklinde sayılmıştır. Örneğin, ailenin toplumun doğal ve temel bir parçası olduğu ve toplum ve devlet tarafından korunması yükümlülüğü (md.13), evrensellik, dayanışma, eşitlik, ayrımcılık yasağı ve yoksul ve savunmasız kimselere pozitif ayrımcılık ilkelerine dayalı olarak; ulusal koşullarını da dikkate alarak üye devletlerin geniş kapsamlı sosyal koruma politika ve programları geliştirme ve yerine getirme yükümlülügü (md. 14), üye devletlerin, yerli halkların, Afrika kökenli halkın ve göçmen toplulukların tarihsel olarak Amerika kıtasına yapmış oldukları katkıyı tanıyarak, bu kesimlerin değerlerinin tanınmasını destekleme yükümlülüğü (md. 15), temel kamu hizmetlerine adil, hakkaniyetli ve ayrımcı olmayan erişim (md. 16), üye devletlerin, herkesin en yüksek sağlık standardından yararlanma hakkı konusundaki yükümlülüğü (md. 17), herkesin ayrımcılık yapılmadan yeterli gıdaya sahip olması ve üye devletlerin açlık ve yetersiz beslenmeyi ortadan kaldırmak için gereken her türlü çabayı gösterme yükümlülüğü (md. 18), herkesin ayrımcılık olmaksızın eğitime hakk1 olduğu ve üye devletlerin, kaliteli ilk ve orta öğretime eşit ve evrensel erişim sağlama ve iç hukuklarına uygun olarak, özellikle anaokulu eğitimi olmak üzere kapsayıcı bir yaklaşımla her düzeyde eğitime erişimi teşvik yükümlülügü (md. 19), üye devletlerin, ulusal yasalar ve politikalar çerçevesinde halkın güvenli içme suyu ve temizlik hizmetlerine ayrımcı olmayan erişiminin sağlanması yükümlülüğü (md. 20), üye devletlerin, yoksullukla mücadele, eşitsizliklerin azaltılması, sosyal kapsamanın desteklenmesi ve doğal kaynakların korunması ve sürdürülebilir kullanımı konusunda yükümlülükleri (md. 21) Şartın üçüncü bölümünde düzenlenmiş ve ayrıca bir sosyal haklar listesine yer verilmemiştir (Şart metni için bakınız: http://www.oas.org/en/27.09.2018).

\section{Amerikan İnsan Hakları Sözleşmesi’nin Düzenlediği Denetim Sistemi}

Amerikan İnsan Hakları Sözleşmesi, hak ihlallerinin denetimi konusunda Amerikalılar arası İnsan Hakları Komisyonu ve Amerikalılar arası İnsan Hakları Mahkemesi adlı iki mekanizmaya görev vermiştir. Komisyon Örgüt Şartı ile Mahkeme ise Sözleşme ile kurulmuştur. Komisyonun üyeleri ve mahkemenin yargıçları 1979 yılında ilk kez seçilerek göreve başlamışlardır (Çelebi, 2012, s. 68).

Amerikan sisteminde Komisyon, Sözleşmeye taraf olup olmadığına bakılmaksızın devletler üzerinde denetim yetkisine sahipken, Mahkeme ise sadece Sözleşme taraflarını ve Mahkemenin yetkisini tanıyan devletleri yargılama yetkisine sahiptir. Komisyon, dilekçeleri incelemenin yanında yerinde ziyaretler de (in loco) yapmakta ve ülke raporları hazırlamaktadır (Ural Uslan ve Güner, 2014, ss. 313-314).

\section{Amerikan Devletleri Örgütü İnsan Hakları Komisyonu}

Komisyon, görevi Amerika kıtasında insan haklarını geliştirmek ve korumak olan Örgütün temel ve özerk bir organıdır. Komisyon, kişisel kapasitede hizmet veren yedi bağımsız üyeden oluşur. 1959 yılında Örgüt tarafından kurulan Komisyonun merkezi Washington'dadır. Komisyon, 1979 yılında kurulan Amerikalılar Arası İnsan Hakları Mahkemesi ile birlikte, Amerikalılar arası sistemde insan haklarını korumakla görevli kurumlardan biridir 
(https://www.oas.org/en/iachr/mandate/what.asp/27.09.2018). Komisyon, kuruluşundan yalnızca 6 yıl sonra, bireysel başvuruları kabul etme, üye ülke hükümetlerinden bilgi isteme ve tavsiyelerde bulunma yetkileriyle donatılmıştır (Aslan, 2012, s. 274). Komisyonun statüsü 1970 yılında yürürlüğe giren Buenos Aires Protokolü ile daha sağlam bir kurumsal temel kazanmıştır. Komisyon artık Amerikan Devletleri Örgütü’nün “özerk bir birimi” olmaktan ziyade, doğrudan Amerikan Devletleri Örgütü’nün "temel organı" kabul edilmiştir (Ural Uslan ve Güner, 2014, s. 314). Bundan böyle Amerikan Devletleri Örgütü'nün resmi bir organı haline gelen Komisyon, hem Örgütün hem de Sözleşmenin organı haline gelmiştir. Fakat başta Amerika olmak üzere bazı Amerikan devletlerinin Sözleşmeye taraf olmadığı göz önüne alındığında Komisyonun önüne gelen olaylarda, farklı iki kaynağı kullanmakla yükümlü olacağı anlaşılmaktadır. Komisyon, Sözleşme tarafı bir ülke ile ilgili bir durumu incelerken Amerikan İnsan Hakları Sözleşmesi’ni, Sözleşme tarafı olmayan bir ülke ile ilgili bir durumu incelerken de Amerikan Devletleri Örgütü'nün bağlayıcı belgelerinden biri olan Bildirgeyi kaynak olarak kullanacaktır.

Şartın 106. maddesi, Komisyonun temel işlevinin "insan haklarının korunmasını ve yerine getirilmesini teşvik etmek ve bu konularda örgütün danışma organı görevi görmek” olduğunu belirtmektedir, Sözleşmenin 41. maddesi Komisyonun başlıca işlevinin "insan haklarına saygıyı geliştirmek ve insan haklarını korumak" olduğunu ifade etmektedir (Ural Uslan ve Güner, 2014, s. 314).

Komisyonun çalışması üç ana sütun üzerine inşa edilmiştir. İlki, bireysel başvuru sistemi, ikincisi, üye devletlerdeki insan hakları durumunun izlenmesi, üçüncüsü, öncelik verilen alanlara ilgi çekmek (https://www.oas.org/en/iachr/mandate/what.asp/27.09.2018).

Komisyonun, bir taraf devletteki insan hakları ihlallerine ilişkin şikâyetleri incelemek, ülkelerle ilgili insan hakları raporları hazırlamak ve yayımlamak, sözleşmenin daha çok devlet tarafindan onaylanmasını sağlamak gibi temel işlevlerinin yanı sıra; Mahkeme önünde bulunmak, anlaşmaların yorumlanmasında danışmanlık yapmak, sözleşmelerde değişiklik önerileri yapmak, üyelerine yaptırım uygulaması amacıyla Örgütü harekete geçirmek gibi görevleri bulunmaktadır. Komisyon, kişiler yahut hükümet dışı organizasyonlar tarafından iletilen şikâyetlerin yanı sıra devletlerarası şikâyetleri de -aleyhine başvurulan devletin bu yetkiyi tanıması koşuluylaincelemektedir (Aslan, 2012, ss. 274-275).

Komisyon, ABD de dahil olmak üzere bölgedeki yirmiden fazla ülkeden gelen bireysel şikayetleri çözümlemiş ve hakkında karar vermiştir. Komisyon tarafından bir düzineden fazla ülke için, özellikle ciddi insan hakları ihlallerini içeren olayları belgeleyen Ülke Raporları yayımlanmış, bunu yoğun ve tekrarlanan izleme faaliyetleri takip etmiştir (Donnelly, 1995, s. 228). 


\section{Rapor Yoluyla Denetim}

Komisyon, bir ülkedeki genel insan hakları durumunu gözlemlemek veya belirli durumları araştırmak için yerinde ziyaretler yapmaya başladığı 1961 yılından bu yana, yirmi üç ülkeye altmış dokuz ziyaret gerçekleştirmiştir. Bir ülkenin genel insan hakları durumunun gözlemine yönelik ziyaretleri ile ilgili olarak, Komisyon bugüne kadar kırk dört özel ülke raporu yayınlamıştır (https://www.oas.org/en/iachr/mandate/what.asp/27.09.2018). Bu raporlardan sonuncusu 21 Haziran 2018 tarihli, Nikaragua hakkındaki rapordur. Bu raporda, Nikaragua'da 18 Nisan 2018'de başlayan sosyal protestolar bağlamında yoğun insan hakları ihlalleri yaşandığı ve devletin bu protestolar kapsamında insan haklarına saygı duyma, koruma ve yerine getirme yükümlülüklerini yerine getirmediği (para. 57) belirtilmiştir. İhlal edilen haklar arasında yaşama hakkı, çocuklara ve gençlere yönelik öldürücü silah kullanılması sebebiyle çocuk ve gençlerin korunma hakları, sağlık ve tıbbi bakım hakları sayılmıştır (https://www.oas.org/en/iachr/reports/country.asp/27.09.2018).

Komisyonun 31 Aralık 2017 tarihinde yayımladığı Guatemala raporunda, ülkede yaşanan silahlı çatışmaların, ekonomik ve sosyal eşitsizliğin, büyük çapta yolsuzluğun, acil ihtiyaçlara yönelik devlet politikası ve programlarının karşılanması için vergilerde yapılan artışın sonucu olarak ortaya çıktığı belirtilmiştir. Guatemala'da 1rk ayrımcılığı, toplumsal eşitsizlik, yoksulluğun yaygınlaşması ve dışlanma, cezasızlık ve adalete erişim eksikliği gibi yapısal sorunlar devam etmekte ve insan haklarına saygı yükümlülügünün gerçekleştirilmesinin önünde tam anlamılla bir barikat gibi durmaktadır (para 471). Raporda belirtildiği üzere devlet, eşitsizlik ve dışlamayı önlemek ve tüm insanların insan haklarından yararlanmasını sağlamak amacıyla yasalar, programlar ve politikalar oluşturma konusunda daha fazla çaba harcamalı ve raporda belirtilen risk alanlarını karşılamak üzere yeterli bütçe ayırmalıdır (para. 473) (https://www.oas.org/en/iachr/reports/country.asp/27.09.2018).

Komisyonun 2017 yılında yapmış olduğu çalışmalara ilişkin yıllık raporunda, 2017-2021 yıllarını kapsayan dönem için 21 numaralı Stratejik Planını hazırladığı belirtilmiştir. Stratejik planda Komisyonun öncelik verdiği bazı konular ve kişi grupları yer almaktadır. Komisyonun öncelikli kabul ettiği kişi grupları; yerli insanlar, kadınlar, göçmenler, mülteciler, vatansız kişiler, insan ticareti mağdurları ve ülke içerisinde yerlerinden edilmiş kişiler, Afrika soyundan olanlar, çocuklar ve yerli haklar, insan hakları savunucuları, özgürlüklerinden alıkonulmuş kişiler, lezbiyen, gey, biseksüel, trans ve interseks kişiler; engelliler ve yaşlılardır. Komisyonun öncelik verdiği üç konudan birisi ise; ekonomik, sosyal, kültürel çevresel haklardır (https://www.oas.org/en/iachr/docs/annual/2017/TOC.asp/ 27.09.2018).

Komisyon, belirlediği bazı tematik alanlarda da raporlar hazırlamaktadır. Komisyon 2018 yılında çocuk hakları ve dostane çözüm yoluna ilişkin olmak üzere iki alanda tematik rapor yayımlamıştır. 1 Mart 2018'de yayımlanan “Amerika Birleşik Devletleri Yetişkin Ceza Yargılaması Sisteminde Çocukların ve Gençlerin Durumu" başlıklı raporda, Komisyon, ülkeye yaptığı ziyaretler ve 
kendisine gelen bilgiler kapsamında, ABD Ceza Yargılaması Sisteminde önemli sayıda çocuğun sürekli olarak yetişkin muamelesi görmesinin çocuğun özel korunmadan yararlanma ve çocuklara özgü bir sistem içerisinde yargılanma temel hakkını ihlal ettiğini belirtmiştir (https://www.oas.org/en/iachr/reports/thematic.asp/27.09. 2018).

1 Mart 2018 tarihinde güncellenmiş ikinci baskısı yayımlanan diğer tematik rapor ise Dostane Çözümün Etkisi başlığını taşımaktadır. Bu raporda, Komisyonun temel görevinin Amerika kıtasında insan haklarının korunması ve desteklenmesi olduğu belirtilmiş, Komisyonun bu görevlerini, ülke ziyaretleri yaparak, belirli bir ülkede ya da konudaki insan hakları durumu ile ilgili raporlar hazırlayarak, ihtiyati tedbirler kabul ederek veya Amerikalılar Arası İnsan Hakları Mahkemesi'nden bu tür tedbirler talep ederek ve bireysel dava sistemi aracillğıyla sunulan dilekçeleri inceleyip Mahkemeye yönlendirerek yerine getirdiği (para. 2) belirtilmiştir. Bireysel başvuru sistemi, başvurunun veya davanın incelenmesinin herhangi bir aşamasında, uyuşmazlık konusu olayla ilgili bir sözleşme ile bağıtlanmış olan bir devletin uluslararası sorumluluğunun olup olmadığını belirlemeye yönelik usulünün yanı sıra, Amerikan İnsan Hakları Sözleşmesi ve Bildirgede ve diğer bölgesel insan hakları düzenlemelerinde yer alan insan haklarına uyulması konusunda dostane çözüme ulaşma imkanını da kapsar. Her ne kadar dostane çözüm Komisyon önünde, Mahkeme ilamı değerinde bir karar anlamına gelmese de taraflarca varılan bu gönüllü anlaşma birçok durumda olduğu gibi anlaşmanın devlet tarafından tanınması ve sorumluluğun kabul edilmesini içerebilir (para. 4). Dostane çözüm yöntemi, mağdur olduğunu iddia eden kişiler ile devlet arasında bir diyalog kurulmasına ve mağdurlara çeşitli tazminat tedbirleri sağlayarak ihlal edilen hakların iadesine ve telafisine imkan sağlar. Dostane çözüm yolu aynı zamanda, gelecekte benzer ihlallerin tekrarlanmaması amacının garanti altına önnmasina verir para. (https://www.oas.org/en/iachr/reports/pdfs/ImpactFriendlySettlement-2018.pdf/27.09.2018).

\section{Başvuru Yoluyla Denetim}

Yukarıda belirtildiği üzere, Komisyon üç temel görev yerine getirmektedir. Bu üç temel görevinden bir tanesi de bireysel başvuruları karara bağlamaktır. Aşağıda Komisyon'un verdiği bireysel başvuru kararlarından güncel olan bazıları örnek kabilinden sunulacaktır.

Komisyonun 29 Kasım 2016 tarihli 47/16 Rapor-12659 Başvuru numaral1, Mirey Trueba Arciniega ve diğerleri v. Meksika kararında, devletin yaşama hakkını gereken her türlü tedbirle koruması yönünde pozitif bir yükümlülük altında olduğunu, kuvvet kullanan devlet görevlilerinin yaralanan veya etkilenen kişilere en kısa zamanda sağlık yardımına erişimi sağlama konusunda yükümlü olduklarını (para. 91) belirtmiştir. Bu nedenle Komisyon, Meksika Devleti'nin bir askeri tarafindan silahla yaralanan ve henüz hayatta olan Trueba'ya zamanında ve acil tıbbi bakım sağlama görevinin bulunduğunu (para. 92), buna ek olarak, Komisyon, durumun ciddiyetine rağmen, devletin mümkün olduğunca hızlı bir şekilde tıbbi yardım bulmak için acil bir müdahale sağlamadı̆̆ı, bu 
sebeple yaşama hakkı ve insani muamele görme hakkını ihlal ettiği sonucuna varmıştır (para. 97). Komisyon, bu başvuruyu 28 Nisan 2018 tarihinde Mahkemeye sunmuş olup, Mahkemece henüz bir karar verilmemiştir (https://www.oas.org/en/iachr/decisions/cases.asp/27.09.2018).

Komisyonun 26 Ocak 2012 tarihli 2/12 Rapor-12094 Başvuru numaral1, Lhaka Honhat Yerlileri (Arazi) Derneği v. Arjantin kararında, hukukun üstünlüğ̈ ilkesinin, devletin, kendisini ulusal ve uluslararası düzeyde bağlayan çevre koruma standartlarını yerine getirmesini gerektirdiği, devletlerin, yerli veya kabile halklarının ve onların üyelerinin insan haklarını korumak için kendi mevzuatlarını uygulama yönünde genel pozitif bir yükümlülüğü olduğunu (para. 236) ifade etmiştir. Devletlerin yerli veya kabile halklarının topraklarına zarar verilmesini önleme genel yükümlülüğü vardır. Devletler yerli halkların doğal ortamlarını, altyapı projelerinin sonuçları yanında tarım, hayvancılık, kerestecilik ve diğer ekonomik faaliyetlerin sonucu olan ve yerli veya kabile halklarının geleneksel kapasitelerini, gıda, su ve geçim faaliyetleri açısından azaltan ekolojik bozulmadan korumak için gerekli önlemleri almalıdırlar (para. 238). Komisyon, sonuç olarak Arjantin'in Lhaka Honhat Yerlileri'nin Amerikan İnsan Hakları Sözleşmesi'nin 21. maddesinde düzenlenen mülkiyet hakkını ihlal ettiği vanaatine varmışır (https://www.oas.org/en/iachr/decisions/court/2018/12094FondoEn. pdf/27.09.2018).

\section{Amerikalılar Arası İnsan Hakları Mahkemesi}

Amerikalılar Arası İnsan Hakları Mahkemesi, 18 Temmuz 1978'de, Grenada'nın onaylama belgesini tevdii ile birlikte Amerikan İnsan Hakları Sözleşmesi'nin yürürlüğe girmesiyle kurulmuştur (Aslan, 2012, s. 277). 22 Mayıs 1979'da Sözleşmeye taraf devletler, Örgütün yedinci özel oturumunda Mahkemeyi oluşturacak ve kişisel kapasiteleri ile çalışacak Mahkeme hakimlerini seçmişlerdir. Mahkemenin ilk duruşması 29 ve 30 Haziran 1979'da Washington'daki Örgütün Genel Merkezinde gerçekleştirilmiştir (http://www.corteidh.or.cr/ index. php/en/about-us/historia-de-lacorteidh/27.09.2018).

1 Temmuz 1978'de, Mahkeme merkezinin Kosta Rika'da kurulmasına ilişkin teklif değerlendirilmiş ve Örgüt Genel Kurulu'nun Kasım 1978'deki altıncı özel oturumunda bu teklif Sözleşme tarafı devletlerce onaylanmıştır. Mahkeme'nin San José/Kosta Rika'daki fiili kuruluşu 3 Eylül 1979 tarihinde gerçekleştirilmiştir. Örgüt Genel Kurulu'nun Dokuzuncu Düzenli Oturumunda, Mahkeme Tüzüğü onaylanmış ve Mahkeme, Ağustos 1980'de Usul Kurallarını onaylamıştır. Kasım 2009'da, Örgüt Genel Kurulu'nun seksen beşinci düzenli oturumunda, Mahkeme önünde halihazırda mevcut tüm davalara uygulanan yeni Usul Kuralları yürürlüğe girmiştir (http://www.corteidh.or.cr/index.php/en/about-us/historia-de-la-corteidh/27.09.2018). Mahkeme 1988 yılında ilk önemli kararını vermiştir (Honduras). Bu rejimde, bireylere Mahkemeye doğrudan başvuru hakkı tanınmamıştır. Başvuru hakkı, taraf devletlere ve Komisyona aittir. Bireyleri ilgilendiren 
konular ancak Komisyon tarafından Mahkemeye götürülebilir. Bunun dışında Mahkeme, istenildiğinde, Örgüt üyelerine, tavsiye niteliğinde görüş verebilir (Donnelly, 1995, s. 228).

Mahkemenin yarg1 fonksiyonu, kararlar alma, koruyucu tedbirler kabul etme ve insan haklarının bireysel ve devletler bazında ihlalleri konusunda yargısal kararlar verme yetkilerini içerir. İnsan haklarını ihlal ettiği öne sürülen devletin, Mahkemenin yargı yetkisini kabul etmemiş olduğu durumlarda, uyuşmazlık yalnızca Komisyona götürülebilir. Eğer ilgili devlet Amerikan İnsan Hakları Sözleşmesi'ni onaylamamışsa, Komisyon bu devlet hakkında Bildirgeye göre karar verir. Bir devlet, Bildirgeyi onaylarken veya daha sonraki bir tarihte veya yalnızca özel bir uyuşmazlık için Mahkemenin yetkisini kabul edebilir. Kabul beyanı koşulsuz veya şartlı olabileceği gibi, belirli bir davaya ilişkin ya da süre olarak sınırlı da olabilir (https://www.crin.org/en/guides/un-internationalsystem/regional-mechanisms/inter-american-court-human-rights/27.09.2018).

Mahkeme, Amerikan İnsan Hakları Sözleşmesi’nin ihlal edildiğine karar verirse, kişiye o hakların sağlanması, uygun hak arama yollarının sağlanması ve varsa zararın tazminine hükmeder. Mahkeme kararlarına uymak zorunludur. Mahkeme ayrıca, Sözleşme kapsamındaki hakları yorumlayarak hukuki görüşünü beyan etmektedir (Yücel Dericiler, 2014, ss. 219-220).

Amerikalılar Arası İnsan Hakları Mahkemesi 15 Eylül 2005 tarihli Mapiripán Massacre v. Colombia kararında ve 1 Temmuz 2006 tarihli Ituango Massacres v. Colombia kararında Kolombiya'daki paramiliter gruplar tarafından gerçekleştirilen katliamları, ekonomik, sosyal ve kültürel hakları koruma görevini ihlal olarak görmüştür. Katliamlar, zorla tahliye ve sivil nüfusun yerinden edilmesine ve evlerinin ve geçim araçlarının kaybedilmesine neden olmuştur. Her iki davada da, devlet, diğer şeylerin yanı sıra, bölgedeki tüm denetimi yapan Kolombiya ordusunun sorumluluğuna dayanarak, sivil nüfusu paramiliter grupların saldırısından korumada başarısızlığa düşmekten sorumlu bulunmuştur (http://www. humanrights.ch/upload/pdf/ 080819_ justiziabilitt_esc.pdf/09.06.2017, s. 46).

Ituango Katliamı Davası'nda Mahkeme ayrıca, Kolombiya ordusunun üyeleri ile yarı askeri grupların ortaklaşa yürüttüğü, sivil halk katliamından sonra faillerin, mağdurların sığırlarını çalarak, çaldıkları sığırları kendi kontrolleri altındaki bölgelere taşımaları için, ücret ödemesi olmaksızın ve şiddet tehdidi altında on yedi köylüyü zorlamalarını, zorla çalıştırma yasağı kapsamında değerlendirmiş ve bu yasağın derhal uygulama yükümlülüğünün kapsamında olduğuna ve ILO’nun 29 numaralı Sözleşmesi 1şığında, Amerikan İnsan Hakları Sözleşmesi'nin 6.2. maddesini (zorla veya zorunlu çalışmanın yasaklanması) ve 7. maddesini (şahsi özgürlük hakkı) yorumlayarak devletin bu hakların ihlalinden sorumlu olduğuna karar vermiştir (http://www.humanrights.ch/upload/pdf/ 080819_justiziabilitt_esc.pdf/09.06.2017, s. 28). 


\section{Sonuç}

Sosyal hakların yargılanabilirliği konusunda asıl mesele yorum meselesidir. Hukuku uygulayanların insan haklarına bakış açısı bu açıdan oldukça önemlidir. Hukuk, en genel tanımıyla, yaptırıma bağlanabilen toplumsal düzen kurallarıdır. Toplumlar statik değil dinamik oldukları için hukuk da toplumların değişen ihtiyaçlarına cevap arayan dinamik bir olgudur. Bu açıdan, sosyal hakların ve hatta tüm insan haklarının halen başlangıçtaki kısır ikilem çerçevesinde yorumlanması çağdışı bir yaklaşımdır. Toplumların gelişimine paralel olarak insan hakları da gelişmekte ve genişlemektedir. Bir insan hakkının, anayasa ile hak olarak kabul edilmesi, şüphesiz ki söz konusu hak açısından önemli güvenceler sağlamakla birlikte, gerçekte malumun ilamıdır. Asıl önemli olan hakkın etkin bir şekilde gerçekleştirilebilirliğinin sağlanmasıdır ve bunun en etkin yolu da yargısal denetimdir. O halde, bir hakkın anayasa ile güvenceye alınıp, gerçekleştirilmesi yönündeki amacın açıç̧a vurgulanmasına rağmen, söz konusu hakkın yargılanamazlığının iddia edilmesi ciddi bir çelişkidir. İnsan haklarının bütünlüğü ve birbirine bağımlılığı ilkesi de insan haklarının diğer türlerinin yanı sıra sosyal hakların da etkin gerçekleştirilebilirliğini yani yargısal güvenceye bağlanmasını gerektirir.

Bugün için pek çok uluslararası ve bölgesel örgüt, yargısal ve yarı yargısal organlar eliyle sosyal hakların gerçekleştirilmesi konusunda denetim yapmaktadır. Bu çalışmada, sosyal hakların gerçekleştirilmesinin Amerikan Devletleri Örgütü Sistemindeki denetimi incelenmiştir. Örgütün, sosyal haklara yer veren başlıca düzenlemeleri Amerikan Devletleri Örgütü İnsan Hakları Bildirgesi ile Amerikan İnsan Hakları Sözleşmesi'dir. Sözleşmede sosyal haklar sayıca az olmakla birlikte, Sözleşmeye ekonomik, sosyal ve kültürel haklar alanında eklenen protokol ile sosyal hakların sayısı artırılmıştır. Sosyal hakların gerçekleştirilmesinin Amerikan Devletleri Örgütü sistemindeki denetimi, Amerikalılar Arası İnsan Hakları Komisyonu ve Amerikalılar Arası İnsan Hakları Mahkemesi eliyle yapılmaktadır. Komisyon, rapor yoluyla ve başvuru yoluyla denetim yapmakta olup, Mahkeme ise taraf devletlerden ve Komisyondan gelen başvurular hakkında karar vermektedir.

Karşılaştırmalı hukukta ve uluslararası hukukta ana akım, sosyal hakların yargılanabilirliği/ gerçekleştirilebilirliği yönünde gelişmektedir. 21. yüzyıl, pozitif devlet edimi gerektiren sosyal hakların da yargılanabilirliğinin sağlandığı yüzyıl olacaktır. Bunu gerçekleştirecek olanlar ise çağdaş/yenilikçi hukukçular (sosyal hakları savunan avukatlar ve akademisyenler) ve hakimler olacaktır. Bu anlamda, karşılaştırmalı hukuku gözlemleyebilen, uluslararası verilerden yararlanabilen, yenilikçi, çağdaş, yorum yapmayı bilen, hukuka olan inancını kaybetmemiş hukukçulara ve özellikle de hakimlere olan ihtiyaç ortadadır. Sosyal hakların gerçekleştirilebilirliğinin sağlanmasında asıl mesele budur. 


\section{Kaynakça}

Aslan, Volkan (2012), “Amerikalılar Arası İnsan Hakları Sistemi”, İnönü Üniversitesi Hukuk Fakültesi Dergisi, Cilt:3, Say1:2, ss. 261-296.

Cavallaro, James L. ve Schaffer, Emily J. (December 2004), "Less as More: Rethinking Supranational Litigation of Economic and Social Rights in the Americas", Hastings Law Journal, Vol. 56, ss. 217-282.

Çelebi, Mustafa Burak (2012), İnsan Haklarının Uluslararası Düzeyde Korunması ve Birleşmiş Milletler Sistemi, Yüksek Lisans Tezi, Selçuk Üniversitesi Sosyal Bilimler Enstitüsü, Danışman: Ali Acar, http://acikerisim.selcuk.edu.tr:8080/ xmlui/bitstream/ handle/123456789/1156/325851.Pdf ?sequence $=1 \&$ is Allowed $=\mathrm{y} /$.

Donnelly, Jack (1995), Teoride ve Uygulamada Evrensel İnsan Hakları (Çev. M. Erdoğan-L. Korkut), Ankara: Yetkin Yayınları.

https://burakgemalmaz.files.wordpress.com/2015/05/02.pdf/25.10.2016.

http://www.corteidh.or.cr/ index. php/en/about-us/historia-de-la-corteidh/27.09.2018.

https://www.crin.org/en/guides/un-international-system/regional-mechanisms/inter-american-court-humanrights/27.09.2018.

http://www. humanrights.ch/upload/pdf/ 080819_justiziabilitt_esc.pdf /09.06.2017.

http://www.oas.org/en/27.09.2018.

https://www.oas.org/en/iachr/decisions/cases.asp/27.09.2018.

https://www.oas.org/en/iachr/decisions/court/2018/12094FondoEn. pdf/27.09.2018.

https://www.oas.org/en/iachr/docs/annual/2017/TOC.asp/27.09.2018.

https://www.oas.org/en/iachr/mandate/what.asp/27.09.2018.

https://www.oas.org/en/iachr/reports/country.asp/27.09.2018.

https://www.oas.org/en/iachr/reports/pdfs/ImpactFriendlySettlement-2018.pdf/27.09.2018.

https://www.oas.org/en/iachr/reports/thematic.asp/27.09.2018.

Ural Uslan, Yurdanur ve Güner, Tuğba (2014), “İnsan Haklarının Bölgesel Düzeyde Korunmasl: Amerikan Sistemi”, Süleyman Demirel Üniversitesi İktisadi ve İdari Bilimler Fakültesi Dergisi, C. 19, S. 2, ss. 309-322.

Whelan, Daniel J. ve Donnelly, Jack (Nov. 2007), "The West, Economic and Social Rights, and the Global Human Rights Regime: Setting the Record Straight”, Human Rights Quarterly, Vol. 29, No:4, ss. 908949.

www.ihop.org.tr/dosya/sozlesme/amerikaninsanhaklariodevleribildirgesi.doc/25.10.2016.

Yücel Dericiler, Özge (2014), Sosyal Haklar ve İnsan Hakları Hukuku Çerçevesinde Devletin YükümlülükleriRefah Devletinin Krizi Ekseninde Bir İnceleme, İstanbul: XII Levha Yayıncılık. 